\title{
Susceptibility patterns of enteroaggregative Escherichia coli associated with traveller's diarrhoea: emergence of quinolone resistance
}

\author{
JORDI VILA, MARTHA VARGAS, JOAQUIM RUIZ, MATEU ESPASA, MARC PUJOL, \\ MANEL CORACHÁN, M. TERESA JIMÉNEZ DE ANTA and JOAQUIM GASCÓN
}

Institut Clínic d'Infeccions i Immunologia, Institut d'Investigacions Biomédiques August Pí i Sunyer (IDIBAPS), Hospital Clínic, University of Barcelona, School of Medicine, Villarroel 170, 08036 Barcelona, Spain

\begin{abstract}
Enteroaggregative Escherichia coli (EAggEC) isolates were identified as a cause of traveller's diarrhoea in $50(9 \%)$ of 517 patients and their antimicrobial susceptibility was determined. Molecular epidemiological characterisation and investigation of the mechanisms of acquisition of quinolone resistance among nalidixic acid-resistant EAggEC strains was performed. Seventeen (34\%) of 50 patients needed antimicrobial therapy, because of persistence of symptoms in nine cases and the severity of symptoms in eight cases. Ampicillin and tetracycline resistance was high, whereas chloramphenicol and co-trimoxazole showed moderate activity and amoxicillin plus clavulanic acid, nalidixic acid and ciprofloxacin showed very good activity. Resistance to nalidixic acid was demonstrated in three isolates, two from patients who had travelled to India. In all three strains the resistance was linked to mutations in the gyr $A$ gene alone or in both gyr $A$ and parC genes. Although ciprofloxacin shows excellent in-vitro activity and could be useful in the treatment of traveller's diarrhoea in patients travelling abroad, it may not be useful in patients who have journeyed to India or to Mexico.
\end{abstract}

\section{Introduction}

Enteroaggregative Escherichia coli (EAggEC) are a less than well-defined category of diarrhoeagenic $E$. coli, as their exact mechanism of pathogenicity is not known. However, they are an important cause of acute and persistent infant diarrhoea in less-developed countries [1-4] and of traveller's diarrhoea [5, 6]. Recently, they have been associated with diarrhoea in industrialised countries [7-9] and with diarrhoea in patients with human immunodeficiency virus infection [10]. EAggEC cause a characteristic adherence pattern to HEp-2 cells as they attach to one another and to the HEp-2 cells [11-13]; this is a plasmid-dependent characteristic [14]. Genes encoding different virulence factors such as bundle-forming fimbriae involved in the adherence and a heat-stable toxin (EAST) have been localised in this plasmid $[14,15]$. EAST, initially reported in EAggEC $[15,16]$, has also recently been found in other types of enteropathogenic E. coli [17].

Received 22 Sept. 2000; revised version received 5 April 2001; accepted 12 April 2001.

*Corresponding author: Dr J. Vila (e-mail: vila@medicina. ub.es).
A specific PCR technique has been developed to detect EAggEC causing diarrhoea [18].

The majority of enteric infections causing diarrhoea do not require antimicrobial therapy. However, in some infections treatment with an antimicrobial agent shortens the duration of shedding in faeces. This could be the case in persistent traveller's diarrhoea caused by EAggEC. Knowledge of local antimicrobial resistance patterns is important in selecting therapy. Therefore, this study reports the in-vitro activities of several selected antimicrobial agents against isolates of EAggEC causing traveller's diarrhoea from patients who had travelled to different tropical countries, in contrast to other published studies which were restricted to certain geographical areas $[19,20]$. The molecular basis of nalidixic acid resistance among nalidixic acidresistant EAggEC isolates was also investigated.

\section{Materials and methods}

Bacteria

During the period 1994-1997, stool specimens from 520 patients with traveller's diarrhoea were analysed. All patients had diarrhoeal illness on arrival in Spain or 
developed it within 2 days of their return. The samples were collected during the acute phase of the diarrhoea and were processed within $2 \mathrm{~h}$ of collection. The stool specimens were cultured for E. coli and other bacterial enteropathogens by conventional methods [21]. Single colony subcultures of all different lactose-fermenting colonial morphotypes growing on MacConkey agar were identified by conventional criteria. These colonies were tested by PCR to detect EAggEC as described elsewhere [22].

\section{Susceptibility testing}

The MICs for the clinical isolates were determined by E-test methods according to standard practice. E-test strips (AB-Biodisk, Sölna, Sweden) were placed radially on Mueller-Hinton Agar plates inoculated with a suspension of 0.5 MacFarland standard density. After overnight incubation at $35^{\circ} \mathrm{C}$, MICs were read at the intersection of the zone of growth inhibition with the strip. E. coli ATCC 25922 was used as a reference strain for quality control.

\section{Amplification of the quinolone-resistant determining regions (QRDR) of the gyrA and parC genes by $P C R$}

PCR was performed as described elsewhere [23, 24]. The PCR reaction was performed in a DNA Thermal Cycler 480 (Perkin-Elmer Cetus, Emeryville, CA, USA). Primers and free nucleotides were removed with a QiaQuick spin PCR purification kit (Qiagen, Chatsworth, CA, USA) according to the manufacturer's instructions; the sample was processed directly for DNA sequencing with a TaqDyeDeoxyTerminator Cycle Sequencing kit (Amersham, Cleveland, $\mathrm{OH}$, USA) and analysed in an automatic DNA sequencer (Applied Biosystems 377A).

\section{Low-frequency restriction analysis of chromosomal DNA}

Genomic DNA for low frequency restriction analysis and pulsed-field gel electrophoresis (PFGE) was prepared in agarose plugs and treated as described previously [25]. One DNA insert was incubated overnight with 50 units of Xba (Promega, Madison, WI, USA) according to the manufacturer's instructions. Resultant DNA fragments were separated in an agarose $1 \% \mathrm{w} / \mathrm{v}$ gel (BioRad, Richmond, CA, USA) that was prepared and run in Tris-borate-EDTA buffer in a contour-clamped homogeneous field apparatus (CHEFDR2, BioRad). The conditions of electrophoresis were $200 \mathrm{~V}$ for $20 \mathrm{~h}$ with pulse times of $1-50 \mathrm{~s}$. Thereafter, the gel was stained with ethidium bromide and photographed.

\section{Results}

\section{Isolation of EAggEC}

EAggEc were isolated from $50(9.6 \%)$ of 520 patients with traveller's diarrhoea. In four patients, another enteropathogen was isolated as well as EAggEC; these were Shigella flexneri, Salmonella enterica serovar Typhimurium, Entamoeba histolytica and Cyclospora cayetanensis. Seventeen (34\%) of 50 patients needed antimicrobial therapy, because of the persistence of symptoms in nine cases and the severity of symptoms in eight cases. All the treated patients received ciprofloxacin and recovery was observed in all. The regions visited by the patients with traveller's diarrhoea caused by EAggEC are shown in Table 1. EAggEC was isolated from patients with traveller's diarrhoea who had travelled to different geographical areas around the world, with frequencies ranging from $2 \%$ to $20 \%$. West Africa, the Indian subcontinent and south-east Asia were the most prevalent areas with $20 \%, 14 \%$ and $15 \%$, respectively.

\section{Antimicrobial susceptibility testing}

The in-vitro susceptibility of the EAggEC isolates to seven antimicrobial agents is shown in Table 2. Ciprofloxacin, nalidixic acid and amoxicillin plus clavulanic acid showed the best activity against EAggEC; all gave MIC50 and MIC90 values below the breakpoint, whereas chloramphenicol and cotrimoxazole showed moderate activity with MIC50 below the breakpoint and MIC90 above the breakpoint. Ampicillin and tetracycline, both with a MIC50 and MIC90 values $>256 \mathrm{mg} / \mathrm{L}$, had the lowest levels of activity.

\section{Characterisation of quinolone-resistant isolates of EAggEC}

Three EAggEC isolates were resistant to nalidixic acid, two of which were isolated from patients travelling to India, representing $12.5 \%$ of the EAggEC isolates from patients who visited that country. The third nalidixic acid-resistant EAggEC isolate was from a traveller to

Table 1. Geographic distribution of EAggEC isolates from patients with traveller's diarrhoea

\begin{tabular}{lcc}
\hline Geographical area & $\begin{array}{c}\text { Number of } \\
\text { patients }\end{array}$ & $\begin{array}{c}\text { Number (\%) of } \\
\text { EAggEC isolates }\end{array}$ \\
\hline East Africa & 35 & $1(3)$ \\
West Africa & 61 & $12(20)$ \\
Central Africa & 12 & $1(8)$ \\
Mahgreb & 47 & $1(2)$ \\
Middle East & 21 & $2(9)$ \\
South-east Asia & 21 & $3(14)$ \\
Indian subcontinent & 106 & $16^{*}(15)$ \\
Central America & 160 & $10^{*}(6)$ \\
South America & 54 & $4(7)$ \\
Total & 517 & $50(9)$ \\
\hline
\end{tabular}

* Of three nalidixic acid-resistant EAggEC isolates, two were from India and one from Central America. 
Table 2. In-vitro susceptibility of 50 EAggEC isolates to seven antimicrobial agents

\begin{tabular}{lccrc}
\hline Antimicrobial agent & MIC Range & MIC50 & MIC90 & $\begin{array}{c}\text { Percent of } \\
\text { isolates } \\
\text { resistant }\end{array}$ \\
\hline Ampicillin & $1->256$ & $>256$ & $>256$ & 52 \\
Amoxicillin/clavulanic acid & $0.75-12$ & 4 & 6 & 0 \\
Chloramphenicol & $1->256$ & 4 & $>256$ & 28 \\
Tetracycline & $1.5->256$ & $>256$ & $>256$ & 64 \\
Trimethoprim-sulphamethoxazole & $0.75->32$ & 0.75 & $>32$ & 48 \\
Nalidixic acid & $1->256$ & 4 & 8 & 6 \\
Ciprofloxacin & $0.003-32$ & 0.012 & 0.023 & 2 \\
\hline
\end{tabular}

Central America. The two isolates (244DV and 164DV) from travellers to India had MICs to ciprofloxacin of 0.064 and $>32 \mathrm{mg} / \mathrm{L}$, respectively, whereas the MICs of nalidixic acid were $>256 \mathrm{mg} / \mathrm{L}$ in both isolates. Isolate 232DV from a traveller to Central America had an MIC to ciprofloxacin of $0.25 \mathrm{mg} / \mathrm{L}$ and to nalidixic acid of $>256 \mathrm{mg} / \mathrm{L}$. PCR amplification of the $\mathrm{gyrA}$ and $\operatorname{parC}$ regions followed by DNA sequencing was used to investigate the implications of mutations in the QRDR of the gyrA and parC genes as a mechanism of acquisition of resistance to quinolones. Isolates 232DV and 244DV showed a mutation at amino acid codon Ser-83 which produced a substitution to Leu and Ala, respectively (Table 3). Meanwhile, isolate 164DV showed two mutations in the QRDR of the gyrA gene and two in the QRDR of the parC gene, which generated substitutions of Ser-83 to Leu and Asp-87 to Asn in the GyrA protein and Ser-80 to Ile and Glu-84 to Gly in the ParC protein (Table 3). The two nalidixic acid-resistant EAggEC isolates from travellers to India were investigated by PFGE to determine their clonal relationship. The DNA patterns obtained by PFGE clearly showed that the two strains were not epidemiologically related (Fig. 1).

\section{Discussion}

Recently, in a case-control study to elucidate the role of EAggEC as a cause of traveller's diarrhoea, Gascón et al. [5] found that EAggEC strains were isolated significantly more often from cases than from controls. Cohen et al. [26] found EAggEC in $12-13 \%$ of the

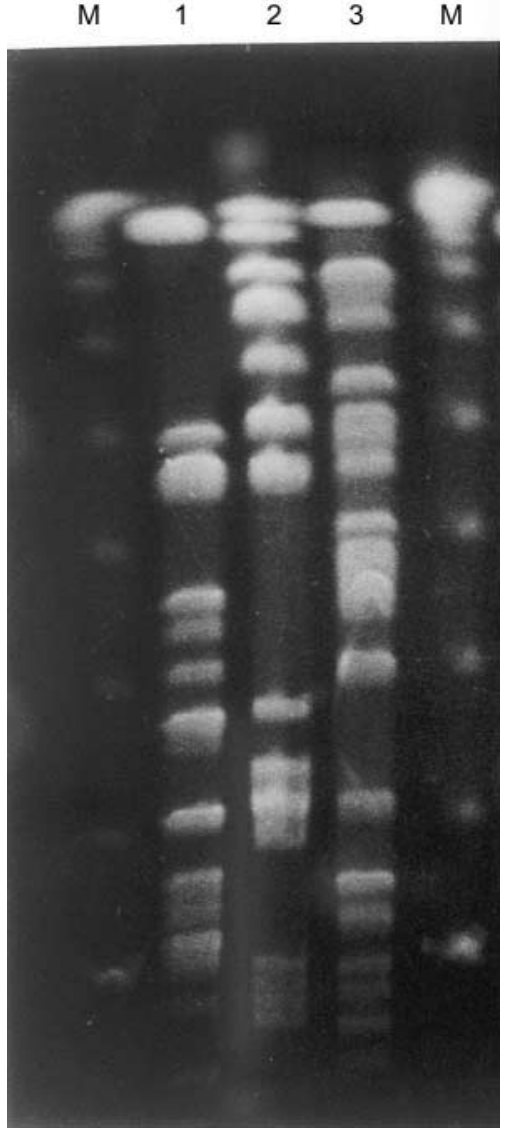

Fig. 1. PFGE of the three nalidixic acid-resistant EAggEC isolates from cases of traveller's diarrhoea. Lane M, DNA molecular mass markers; 1, isolate 164DV (travel to India); 2, 232 DV (travel to Central America); 3, 244 DV (travel to India).

Table 3. Mutations in the $g y r A$ and parC genes of quinolone-resistant clinical isolates of EAggEC

\begin{tabular}{lccllllll}
\hline & \multicolumn{2}{c}{ MIC $(\mathrm{mg} / \mathrm{L})$} & & \multicolumn{3}{c}{ Amino acid change in } \\
\cline { 2 - 3 } \cline { 6 - 8 } Isolates & Cip & Nal & & \multicolumn{2}{c}{ GyrA } & ParC \\
\hline Wild-type & $\ldots$ & $\ldots$ & & Ser-83 & Asp-87 & Ser-80 & Glu-84 \\
244DV & 0.064 & 48 & & Ala & $\ldots$ & $\ldots$ & $\ldots$ \\
232DV & 0.25 & 256 & & Leu & $\ldots$ & $\ldots$ & $\ldots$ \\
164DV & $>32$ & $>256$ & & Leu & Asn & Ile & Gly \\
\hline
\end{tabular}

Cip, ciprofloxacin; Nal, nalidixic acid. 
patients who have travelled to Central or South America, the Caribbean or Mexico. In contrast, the results of the present study showed that the prevalence of EAggEC causing traveller's diarrhoea in travellers to Central and South America was 6\% and 7\% respectively. In the present study, the most prevalent area was West Africa (20\%), and although no studies have been performed before in travellers to this geographical area, persistent diarrhoea caused by multidrug-resistant EAggEC has recently been reported in Kenyan [19] and Tanzanian [27] children. Another area of high prevalence found in the present study was the Indian subcontinent $(15 \%)$. The importance of EAggEC as a cause of diarrhoea in children in this geographical area has been shown in several studies [1, 28, 29].

Knowledge of local antimicrobial resistance patterns is important in selecting therapy, as susceptibilities for an isolate will generally not be known until $72 \mathrm{~h}$ after the sample is processed. The present study did not find major differences in antimicrobial resistance among EAggEC from different geographical areas. Overall, they show a high to moderate level of resistance to ampicillin, tetracycline, co-trimoxazole and chloramphenicol. The emergence of resistance to these antimicrobial agents in other enteropathogens causing traveller's diarrhoea has also been described [28, 3033]. Amoxicillin plus clavulanic acid, nalidixic acid and ciprofloxacin showed the best activity against EAggEC. Yamamoto et al. [20] investigated the invitro susceptibilities of EAggEC strains to various antimicrobial agents, demonstrating the appearance of marked drug resistance. However, this study was restricted to certain geographical areas - of 63 EAggEC strains analysed, 10 strains were from Mexico, Chile and Peru and 53 strains were from Thailand. The percentage of strains resistant to cotrimoxazole was $34.9 \%$, a little lower than that found in the present study (48\%). They suggested the potential usefulness of some antimicrobial agents, such as the fluoroquinolones, as no quinolone-resistant strains were found in their study. However, in the present study, three EAggEC isolates were resistant to nalidixic acid and one of them was also highly resistant to ciprofloxacin. Of these three isolates, two were from travellers to India and the third from a traveller to Central America. Analysis of the two nalidixic acid-resistant isolates from India by PFGE demonstrated that they were not epidemiologically related.

The nalidixic acid resistance in these three EAggEC isolates was due to a mutation in amino acid codon Ser-83 of the gyrA gene in the isolates resistant to nalidixic acid but susceptible to ciprofloxacin and to four mutations, two in the gyrA gene and two in the $\operatorname{par} C$ gene, in the isolate that was resistant to nalidixic acid and ciprofloxacin. This confirms previous findings that high-level resistance to ciprofloxacin in E. coli is related to the presence of concomitant mutations in the gyrA and parC genes [23, 24].
The fluoroquinolones have received considerable attention and have been shown to be highly effective in reducing the duration of traveller's diarrhoea [34-37]. Recently, Glandt et al. [6] showed a significant reduction in the duration of post-treatment diarrhoea and a non-significant reduction in the mean number of unformed stools passed during the $72 \mathrm{~h}$ after enrolment in the ciprofloxacin-treated group as compared with that of the placebo group.

In summary, oral antimicrobial agents commonly used to treat bacterial diarrhoea, particularly co-trimoxazole, have poor in-vitro activity against EAggEC. Despite the excellent in-vitro activity of ciprofloxacin, demonstrating its possible usefulness in the treatment of diarrhoea in patients travelling abroad, the possibility of resistance to this antimicrobial agent should be considered in patients with traveller's diarrhoea who have journeyed to India or to Mexico.

This work was supported in part by grant no. SAF97/0091 from the Comisión Interministerial de Ciencia y Tecnología, Plan Nacional $\mathrm{I}+\mathrm{D}$, Spain, and by a fellow of the Sociedad Española de Medicina Trópical y Salud Internacional. M.V. has a fellowship from the Ministerio de Educación y Cultura of Spain.

\section{References}

1. Bhan MK, Raj P, Levine MM et al. Enteroaggregative Escherichia coli associated with persistent diarrhea in a cohort of rural children in India. J Infect Dis 1989; 159: 1061-1064.

2. Cravioto A, Tello A, Navarro A et al. Association of Escherichia coli HEp-2 adherence patterns with type and duration of diarrhoea. Lancet 1991; 337: 262-264.

3. Kang G, Mathan MM, Mathan VI. Evaluation of a simplified HEp-2 cell adherence assay for Escherichia coli isolated from South Indian children with acute diarrhea and controls. J Clin Microbiol 1995; 33: 2204-2205.

4. Wanke CA, Schorling JB, Barrett LJ, DeSouza MA, Guerrant RL. Potential role of adherence traits of Escherichia coli in persistent diarrhea in an urban Brazilian slum. Pediatr Infect Dis 1991; 10: 746-751.

5. Gascón J, Vargas M, Quintó L, Corachán M, Jiménez de Anta MT, Vila J. Enteroaggregative Escherichia coli strains as a cause of traveler's diarrhea: a case-control study. J Infect Dis 1998; 177: 1409-1412.

6. Glandt M, Adachi JA, Mathewson JJ et al. Enteroaggregative Escherichia coli as a cause of traveler's diarrhea: clinical response to ciprofloxacin. Clin Infect Dis 1999; 29: 335-338.

7. Čobeljić M, Miljković-Selimović B, Paunović-Todosijević D et al. Enteroaggregative Escherichia coli associated with an outbreak of diarrhoea in a neonatal nursery ward. Epidemiol Infect 1996; 117: 11-16.

8. Itoh Y, Nagano L, Kunishima M, Ezaki T. Laboratory investigation of enteroaggregative Escherichia coli O untypeable:H10 associated with a massive outbreak of gastrointestinal illness. J Clin Microbiol 1997; 35: 2546-2550.

9. Smith HR, Cheasty T, Rowe B. Enteroaggregative Escherichia coli and outbreaks of gastroenteritis in UK. Lancet 1997; 350: $814-815$.

10. Mayer HB, Wanke CA. Enteroaggregative Escherichia coli as a possible cause of diarrhea in an HIV-infected patient. $N$ Engl $J$ Med 1995; 332: 273-274.

11. Nataro JP, Kaper JB, Robins-Browne R, Prado V, Vial P, Levine MM. Patterns of adherence of diarrheagenic Escherichia coli to HEp-2 cells. Pediatr Infect Dis J 1987; 6: 829-831.

12. Vial PA, Robins-Browne $\mathrm{R}$, Lior $\mathrm{H}$ et al. Characterization of enteroadherent-aggregative Escherichia coli, a putative agent of diarrheal disease. $J$ Infect Dis 1988; 158: 70-79.

13. Vial PA, Mathewson JJ, DuPont HL, Guers L, Levine MM. 
Comparison of two assay methods for patterns of adherence to HEp-2 cells of Escherichia coli from patients with diarrhea. $J$ Clin Microbiol 1990; 28: 882-885.

14. Nataro JP, Deng Y, Maneval DR, German AL, Martin WC, Levine MM. Aggregative adherence fimbria I of enteroaggregative Escherichia coli mediate adherence to HEp-2 cells and hemagglutination of human erythrocytes. Infect Immun 1992; 60: $2297-2304$

15. Savarino SJ, Fasano A, Watson $\mathrm{J}$ et al. Enteroaggregative Escherichia coli heat-stable enterotoxin-1 represents another subfamily of E. coli heat-stable toxin. Proc Natl Acad Sci USA 1993; 90: 3093-3097.

16. Savarino SJ, Fasano A, Robertson DC, Levine MM. Enteroaggregative Escherichia coli elaborate a heat-stable enterotoxin demonstrable in an in vitro rabbit intestinal model. $J$ Clin Invest 1991; 87: 1450-1455.

17. Savarino SJ, McVeigh A, Watson $\mathrm{J}$ et al. Enteroaggregative Escherichia coli heat-stable enterotoxin is not restricted to enteroaggregative E. coli. J Infect Dis 1996; 173: 1019-1022.

18. Schmidt H, Knop C, Franke S, Aleksic S, Heesemann J, Karch H. Development of PCR for screening of enteroaggregative Escherichia coli. J Clin Microbiol 1995; 33: 701-705.

19. Sang WK, Oundo JO, Mwituria JK et al. Multidrug-resistant enteroaggregative Escherichia coli associated with persistent diarrhea in Kenyan children. Emerg Infect Dis 1997; 3: 373-374.

20. Yamamoto T, Echeverria P, Yokota T. Drug resistance and adherence to human intestines of enteroaggregative Escherichia coli. J Infect Dis 1992; 165: 744-749.

21. Murray PR, Baron EJ, Pfaller MA, Tenover FC, Yolken RH Manual of clinical microbiology, 6th edn. Washington, DC, ASM Press. 1995.

22. Vargas M, Gascón J, Gallardo F, Jimenez de Anta MT, Vila J. Prevalence of diarrheagenic Escherichia coli strains detected by PCR in patients with traveler's diarrhea. Clin Microbiol Infect 1989; 4: 682-688.

23. Vila J, Ruiz J, Marco F et al. Association between double mutation in gyrA gene of ciprofloxacin-resistant clinical isolates of Escherichia coli and MICs. Antimicrob Agents Chemother 1994; 38: 2477-2479.

24. Vila J, Ruiz J, Goñi P, Jiménez de Anta MT. Detection of mutations in $\operatorname{parC}$ in quinolone-resistant clinical isolates of Escherichia coli. Antimicrob Agents Chemother 1996; 40: 491-493.

25. Matushek MG, Bonten MCM, Hayden MK. Rapid preparation of bacterial DNA for pulsed-field gel electrophoresis. J Clin
Microbiol 1996; 34: 2598-2600.

26. Cohen MB, Hawkins JA, Weckbach LS, Staneck JL, Levine MM, Heck JE. Colonization by enteroaggregative Escherichia coli in travellers with and without diarrhea. J Clin Microbiol 1993; 3I: 351-353.

27. Vila J, Vargas M, Casals C et al. Antimicrobial resistance of diarrheagenic Escherichia coli isolated from children under the age of 5 years from Ifakara, Tanzania. Antimicrob Agents Chemother 1999; 43: 3022-3024.

28. Bhan MK, Bhandari N, Sazawal S et al. Descriptive epidemiology of persistent diarrhoea among young children in rural northern India. Bull World Health Organ 1989; 67: 281-288.

29. Paul M, Tsukamoto T, Ghosh AR et al. The significance of enteroaggregative Escherichia coli in the etiology of hospitalized diarrhoea in Calcutta, India and the demonstration of a new honey-combed pattern of aggregative adherence. FEMS Microbiol Lett 1994; 117: 319-325.

30. Gallardo F, Gascón J, Ruiz J, Corachán M, Jiménez de Anta MT, Vila J. Campylobacter jejuni as a cause of traveler's diarrhea: clinical features and antimicrobial susceptibility. J Travel Med 1998; 5: 23-26.

31. Murray BE. Resistance of Shigella, Salmonella, and other selected enteric pathogens to antimicrobial agents. Rev Infect Dis 1986; 8 (Suppl 2): S172-S181.

32. Vila J, Gascón J, Abdalla $\mathrm{S}$ et al. Antimicrobial resistance of Shigella isolates causing traveler's diarrhea. Antimicrob Agents Chemother 1994; 38: 2668-2670.

33. Vila J, Gascón J, Abdalla $\mathrm{S}$ et al. Antimicrobial resistance of nontyphoidal Salmonella isolates in traveler's diarrhea. J Travel Med 1993; 2: 45-47.

34. DuPont HL, Ericsson CD, Mathewson JJ, DuPont MW. Five versus three days of ofloxacin therapy for travelers' diarrhea: a placebo-controlled study. Antimicrob Agents Chemother 1992; 36: $87-91$.

35. Ericsson CD, Johnson PC, DuPont HL, Morgan DR, Bitsura JAM, de la Cabada FJ. Ciprofloxacin or trimethoprimsulfamethoxazole as initial therapy for traveler's diarrhea. Ann Intern Med 1987; 106: 216-220.

36. Taylor DN, Sanchez JL, Candler W, Thornton S, McQueen C, Echevarria P. Treatment of travelers' diarrhoea: ciprofloxacin plus loperamide compared with ciprofloxacin alone. A placebocontrolled, randomized trial. Ann Intern Med 1991; 114: $731-734$.

37. Wiström J, Jertborn M, Hedström SÅ et al. Short-term selftreatment of travellers' diarrhoea with norfloxacin: a placebocontrolled study. J Antimicrob Chemother 1989; 23: 905-913. 